\title{
Multiplex PCR Assay for the Identification of Four Species of the Anopheles Leucosphyrus Sub-Group in Malaysia
}

\author{
Sandthya Pramasivan ${ }^{1}$, Jonathan Wee Kent Liew ${ }^{1,2} \mathbb{D}$, Nantha Kumar Jeyaprakasam ${ }^{1}$ (D), Van Lun Low ${ }^{3} \mathbb{D}^{\text {, }}$ \\ Romano Ngui ${ }^{1,4}$ and Indra Vythilingam $1, *$ (D)
}

1 Department of Parasitology, Faculty of Medicine, University Malaya, Kuala Lumpur 50603, Malaysia; sandthya96@gmail.com (S.P.); jonathan_liew@nea.gov.sg (J.W.K.L.); j_nanthakumar@hotmail.com (N.K.J.); romano@um.edu.my (R.N.)

2 Environmental Health Institute, National Environment Agency, Singapore 228231, Singapore

3 Tropical Infectious Diseases Research \& Education Centre (TIDREC), University Malaya, Kuala Lumpur 50603, Malaysia; vanlun_low@um.edu.my

4 Malaria Research Centre, Faculty of Medicine and Health Sciences, University Malaysia Sarawak (UNIMAS), Kota Samarahan 94300, Malaysia

* Correspondence: indrav@um.edu.my

check for updates

Citation: Pramasivan, S.; Liew, J.W.K.; Jeyaprakasam, N.K.; Low, V.L.; Ngui, R.; Vythilingam, I. Multiplex PCR Assay for the Identification of Four Species of the Anopheles Leucosphyrus Sub-Group in Malaysia. Insects 2022, 13, 195. https://doi.org/10.3390/ insects13020195

Academic Editors: Andre Barreto Bruno Wilke and Mauro

Toledo Marrelli

Received: 18 December 2021 Accepted: 11 February 2022 Published: 13 February 2022 Corrected: 17 May 2022

Publisher's Note: MDPI stays neutral with regard to jurisdictional claims in published maps and institutional affiliations.

Copyright: (C) 2022 by the authors. Licensee MDPI, Basel, Switzerland. This article is an open access article distributed under the terms and conditions of the Creative Commons Attribution (CC BY) license (https:// creativecommons.org/licenses/by/ $4.0 /)$.
Simple Summary: Plasmodium parasites cause malaria. The bites of infected female Anopheles mosquitoes, known as "malaria vectors," transmit the parasites to people. To prevent the spread of malaria, precise mosquito species identification is essential. This study aims to develop a quick and accurate method for identifying the Anopheles species (An. introlatus, An. latens, An. cracens, and An. balabacensis), which have been incriminated as vectors for simian malaria in Malaysia. Overall, six primers targeting the internal transcribed spacer 2 (ITS2) region of each species were designed for this assay. This study is helpful for the researchers or vector-related field workers to correctly identify the mosquitoes for control activities.

Abstract: The Leucosphyrus Group of mosquitoes are the major simian malaria vectors in Malaysia. Accurate species identification is required to help in curbing the spread of simian malaria. The aim of the study is to provide an accurate molecular method for identifying the four important Anopheles vector species found in Malaysia. Mosquito specimens were collected from various localities in Malaysia, where simian malaria cases were reported. DNA from 122 mosquito specimens was tested to develop a multiplex polymerase chain reaction (PCR) assay. The specificity of this assay was tested against other mosquito species. Molecular identification of the species was further confirmed by analysing the internal transcribed spacer 2 (ITS2) DNA region of the specimens. Anopheles balabacensis and An. latens showed two distinct clades in the phylogenetic tree. The multiplex PCR assay was developed based on the ITS2 region for the identification of Anopheles introlatus (298-299 bp), Anopheles latens (197-198 bp), Anopheles cracens (421-426 bp), and Anopheles balabacensis (224-228 bp). This method will be useful to accurately identify the major Anopheles Leucosphyrus Group species in Malaysia, which are difficult to identify morphologically, to determine the correct vector as well as its geographical distribution.

Keywords: species identification; multiplex PCR assay; Anopheles; simian malaria; ITS2; Malaysia

\section{Introduction}

Malaria continues to be a public health issue in many tropical countries, especially Africa [1], while in the Asian region, malaria was eradicated from Sri Lanka in 2016 [2] and recently from China [3]. Malaysia is in the pipeline for malaria elimination as no indigenous human malaria cases have been reported since 2018 [4]. However, in Southeast Asia, humans have been infected with Plasmodium knowlesi, a simian malaria. [5]. Moreover, P. cynomolgi [6-10] and P. inui have also been reported in humans [11,12]. In Malaysia, 
P. knowlesi is the predominant species affecting humans, and 3212 cases have been reported in 2019 [13]. The Anopheles Leucosphyrus Group of mosquitoes has been incriminated as the vectors of simian malaria [14]. There are 20 named species under the Leucosphyrus Group in the Neomyzomyia series $[15,16]$. This group is further classified into the Hackeri, Leucosphyrus, and Riparis subgroups. The Leucosphyrus sub-group consists of Dirus (seven sibling species) and Leucosphyrus (five sibling species) complexes $[17,18]$ which are morphologically similar in all life phases $[15,17,18]$. Seven species, classified into three subgroups mentioned above, exist in Malaysia. The major simian malaria vectors of Malaysia belonging to the Anopheles Leucosphyrus Group are as follows: Leucosphyrus complex (An. latens, An. introlatus, An. balabacensis [19-21]); Dirus complex (An. cracens [22]); and Hackeri sub-group: An. hackeri [23]. Members of the Riparis sub-group An. macarthuri and An. pujutensis (Hackeri sub-group) are found in Malaysia but have not been incriminated as vectors thus far, although An. pujutensis has been suspected as a vector [14].

In the fight against malaria, one of the greatest challenges is the identification of these vectors based on morphological characteristics. Since each species has a unique role in malaria transmission, phenotypic misidentification is likely to have a significant influence on malaria vector strategy and control in specific areas [18,24-29]. Misidentification of these species can be a significant issue to the public health authorities performing vector control activities. For example, An. introlatus had been mistakenly recognised as An. latens morphologically [30]. Both species occur sympatrically and are difficult to be identified morphologically [17,31-33]. As a result, other techniques are required to identify these species.

Mosquitoes belonging to species complexes can be differentiated using various methods such as cross-breeding experiments, electrophoretic variation at enzymes loci, chromosome banding patterns, and molecular investigations [29]. Currently, molecular analysis to identify the species (using multiplex PCR assays) is often carried out in laboratories. This is because correct species identification is required for studies such as vector incrimination, pesticide susceptibility evaluations, and vector geographical distribution.

The tools for precise identification of the Leucosphyrus Group of Anopheles mosquitoes, which are simian malaria vectors, are not well established in Malaysia. This is due to the fact that these species had a very minor role in human malaria transmission in Peninsular Malaysia, albeit a major vector in Malaysian Borneo (An. balabacensis and An. latens). However, An. dirus complex has been well studied and plays a major role in human malaria transmission in the Greater Mekong Region [34]. The An. dirus complex can be distinguished by polytene, mitotic chromosomes, isoenzyme electrophoresis, DNA probes, PCR-RFLP, and non-radioactive DNA hybridisation [35-43]. However, these techniques have major drawbacks that limit their extensive usage in research because they require specific technical skill and knowledge for cytotaxonomy test, frozen material needed for isozymes, a large amount of DNA such as three to five mosquitoes per well for PCR-RFLP, or they allow the identification of only one, two or three species in DNA probes or nonradioactive DNA hybridisation. Hence, multiplex PCR has been developed to identify the An. dirus complex [44,45]. Despite the availability of these identification techniques for vector epidemiological studies, a simpler and more robust methodology is required.

Thus, the aim of this study is to create a fast and accurate identification method to distinguish four species of the major Leucosphyrus Group of Anopheles mosquitoes in Malaysia, i.e., An. introlatus, An. latens, An. cracens, and An. balabacensis. The use of molecular markers is more field-friendly for identifying anopheline mosquitoes because very little tissue (e.g., legs of the mosquitoes) is required.

\section{Materials and Methods}

\subsection{Sample Collection}

Four species of female Anopheles mosquitoes, namely An. balabacensis, An. introlatus, An. cracens, An. latens clade I and An. latens clade II [46] used in the study were collected from different states in Malaysia, namely Johor, Kelantan, Pahang, Selangor, Sabah, and Sarawak, where most simian malaria infections were reported [47] (Figure 1) (Table S1). Mosquitoes 
were collected using bare-leg capture (BLC) [48] as well as human baited trap, CDC light trap, and mosquito magnet from 18:00 to 23:30 as described in the work of [49]. The Anopheles mosquitoes were morphologically identified using the keys of Reid [50] and Sallum [18].
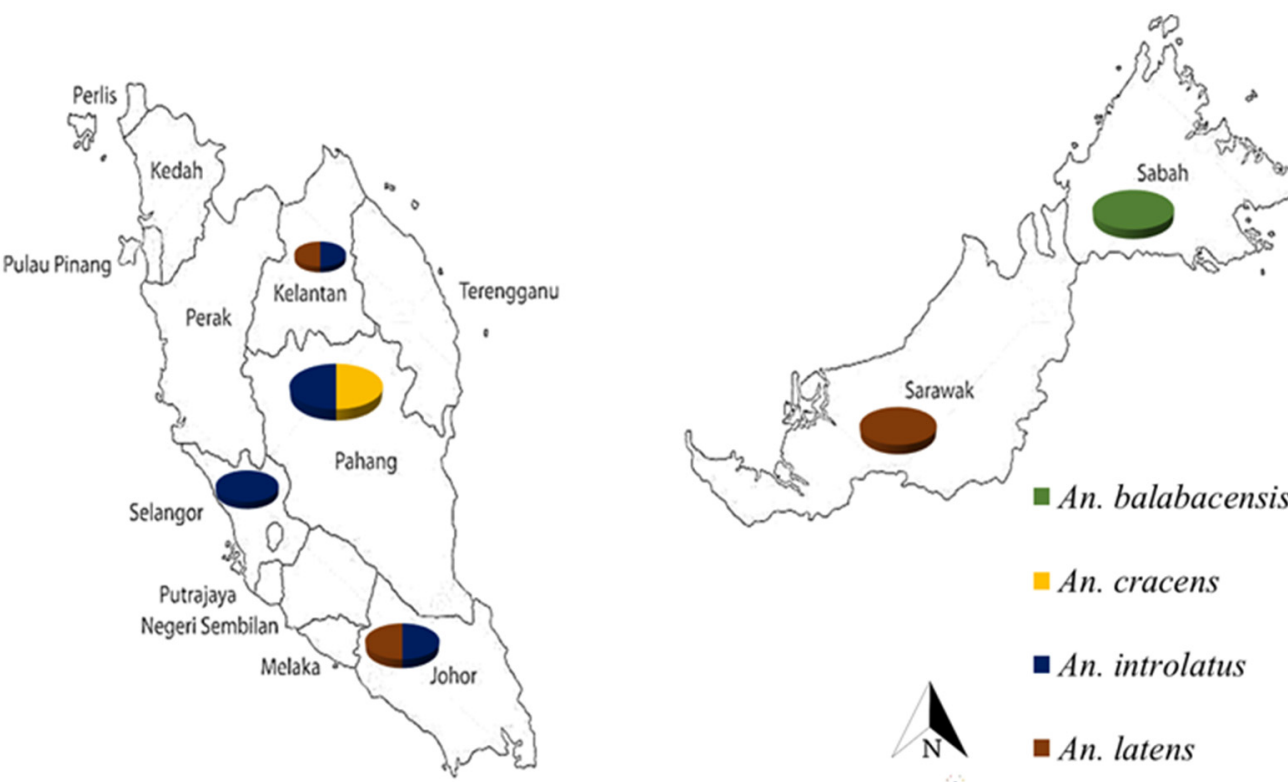

Figure 1. Mosquito sampling sites by species collected from Peninsular Malaysia and Malaysian Borneo (Sabah and Sarawak).

\subsection{DNA Extraction and Molecular Identification of Field Caught Anopheles}

DNA was extracted from the mosquitoes' legs using either InstaGene Matrix (BioRad, Hercules, CA, USA) or DNeasy ${ }^{\circledR}$ tissue Kit (Qiagen, Germany) according to the manufacturers's protocol. The extracted DNA was kept at $-20{ }^{\circ} \mathrm{C}$ until required. All Anopheles mosquitoes from the Leucosphyrus Group obtained in this study, including some archive samples, were further molecularly characterised using the internal transcribed spacer 2 (ITS2) region and mitochondrial cytochrome c oxidase subunit I (COI) gene. The ITS2 was amplified by ITS2A and ITS2B primers [24], the PCR conditions were as follows: denaturation at $95{ }^{\circ} \mathrm{C}$ for $2 \mathrm{~min}, 35$ cycles of amplification at $95^{\circ} \mathrm{C}$ for $30 \mathrm{~s}$, annealing step at $51{ }^{\circ} \mathrm{C}$ for $30 \mathrm{~s}$ with elongation step at $72{ }^{\circ} \mathrm{C}$ for $1 \mathrm{~min}$, followed by final elongation step of $10 \mathrm{~min}$ at $72{ }^{\circ} \mathrm{C}$. LCO1490 and HCO2198 primers [29] were used to amplify the COI gene. The PCR conditions were as follows: denaturation at $95^{\circ} \mathrm{C}$ for $3 \mathrm{~min}, 35$ cycles of amplification at $95{ }^{\circ} \mathrm{C}$ for $1 \mathrm{~min}$, annealing step at $50{ }^{\circ} \mathrm{C}$ for $1 \mathrm{~min}$ with elongation step at $72{ }^{\circ} \mathrm{C}$ for $1 \mathrm{~min}$, followed by final elongation step of $10 \mathrm{~min}$ at $72{ }^{\circ} \mathrm{C}$ and held at a temperature of $4{ }^{\circ} \mathrm{C}$. Each reaction mixture of $25 \mu \mathrm{L}$ contained $5 \mu \mathrm{L}$ DNA template, $0.5 \mu \mathrm{M}$ primers, respectively, $0.2 \mathrm{mM}$ dNTP, $3 \mathrm{mM} \mathrm{MgCl}_{2}, 1 \times \mathrm{GoTaq}^{\circledR}$ Flexi Buffer, and $1.0 \mathrm{U}$ of GoTaq $^{\circledR}$ DNA polymerase (Promega Corporation, Madison, WI, USA). This master mix was used for both primer sets. Amplicons were subjected to electrophoresis on 1.5\% agarose gels. The amplified product was purified from the gel and sequenced. All the sequences were checked against those in the Gene Bank using BLAST. A species is confirmed by $\geq 98 \%$ identity percentage and query coverage to the deposited sequence.

\subsection{Sequence Analysis}

The ITS2 sequences from representative An. balabacensis, An. cracens, An. introlatus and $A n$. latens samples collected from different areas were used. Sequences were aligned with other deposited sequences obtained from the NCBI Gene Bank using BioEdit (Version 7.2). MEGA-X (Version 10.1.8) was used to generate a phylogenetic tree using maximum-likelihood (ML) with 1000 bootstrap replicates. Sequences obtained from this 
study were deposited in the NCBI Gene Bank An. cracens, MZ575625-MZ57532; An. introlatus, MZ575650-MZ575658; An. latens, MZ575633-MZ575635, MW587948-MW587950.

\subsection{Primer Design}

ITS2 DNA sequences were used to design Anopheles species-specific primers in this study [44-49,51-57]. Single-round multiplex PCR was designed based on species-specific variations in the sequences of the ITS2, a ribosomal DNA gene (rDNA) commonly used to distinguish cryptic Anopheles species, particularly those belonging to Asian complexes and groups [44,45,51-57]. Previously published ITS2 sequences and ITS2 sequences obtained from this study were included: An. balabacensis (KY883194-KY883201, KC508607-KC508611, JQ424794.1-JQ424825, MG008613-MG008624), An. introlatus (MG008577-MG008586, KM032613), An. cracens (KJ462197-KJ462201, MG008561-MG008576) and An. latens (MG008596-MG008612, MW587948-MW587956). The sequences were aligned using Clustal Omega software programme to obtain a consensus sequence for each species. Then, these species-specific consensus sequences were aligned together, and specific sites for primer design were manually selected for each species. After selection of the regions, primers were designed using PrimerOuest ${ }^{\mathrm{TM}}$ tool programme. For the four Anopheles species found in Malaysia, a universal forward primer and species-specific reverse primers were developed.

\subsection{Multiplex PCR Assay for Four Anopheles Species}

Each primer was tested with 122 mosquito samples comprising of the four species from the Leucosphyrus group (An. balabacensis (21), An. cracens (25), An. introlatus (30) and An. latens (23), as well as with other mosquito species (two each of An. dirus, An. maculatus, An. donaldi, An. minimus, An. barbirostris, An. sinensis, An. aconitus, and three each of Ae. aegypti, Ae. albopictus, and Armigeres subalbatus) to check the length of the amplified fragment and determine primer specificity. Molecularly confirmed species were used as positive controls. Non-template control (NTC) was used as a negative control. The PCR was carried out using $25 \mu \mathrm{L}$ volume containing 1 unit of GoTaq ${ }^{\circledR}$ G2 Flexi DNA Polymerase, $1 \times$ GoTaq $^{\circledR}$ Flexi Buffer, $1.5 \mathrm{mM} \mathrm{MgCl}_{2}$ (Promega, Madison, WI, USA), $0.2 \mu \mathrm{M}$ dNTP, each primer at $0.1 \mu \mathrm{M}$ and $2 \mu \mathrm{L}$ of extracted DNA. The PCR conditions were as follows: $95{ }^{\circ} \mathrm{C}$ for $2 \mathrm{~min}$, followed by 40 cycles at $95^{\circ} \mathrm{C}$ for $30 \mathrm{~s}$, and $68^{\circ} \mathrm{C}$ for 1 min $15 \mathrm{~s}$, with a final extension step at $72{ }^{\circ} \mathrm{C}$ for $10 \mathrm{~min}$ and held at a temperature of $4{ }^{\circ} \mathrm{C}$. The PCR products were subjected to electrophoresis on a $1.5 \%$ agarose gel.

\section{Results}

Phylogenetic tree based on the ML approach showed that the An. introlatus and An. cracens collected in different areas where known malaria cases occurred formed their respective monophyletic clade (Figure 2). However, An. balabacensis and An. latens formed more than one clade. An. latens associated with the populations from East and West Malaysia were observed in the tree constructed from the ITS2.

Six primers were developed based on the ITS2 sequence alignment (Table 1), and the specificity of each primer was tested.

Table 1. Universal forward primer and the five Anopheles species-specific reverse primers (from this study) for An. latens, An. introlatus, An. cracens, and An. balabacensis with the sequences and the product size.

\begin{tabular}{cccc}
\hline & Primer's Name & Sequences & Product Sizes (bp) \\
\hline Universal forward primer & LeucogrpFwd & 5'-GCG YCG CTG GCC TGC ACG-3' $^{\prime}$ & - \\
An. balabacensis & balabaRev & $5^{\prime}$-CGG CGC AGC GAC TCY ACC G-3' & $224-228$ \\
An. cracens & craRev4 & 5'-GC ACC GCT CTT GGC GGG ATA T-3' $^{\prime}$ & $421-426$ \\
An. introlatus & introRev3 & $5^{\prime}-$ CG ACG AGC GCG YGA GCG A-3' & $298-299$ \\
An. latens Clade I & laten1Rev & $5^{\prime}-$ CCC GGG CGT CCG GTG TTT-3' & 198 \\
An. latens Clade II & laten2Rev & 5'-CCG GGC GTC YGC GGT GTA C-3' $^{\prime}$ & 197 \\
\hline
\end{tabular}




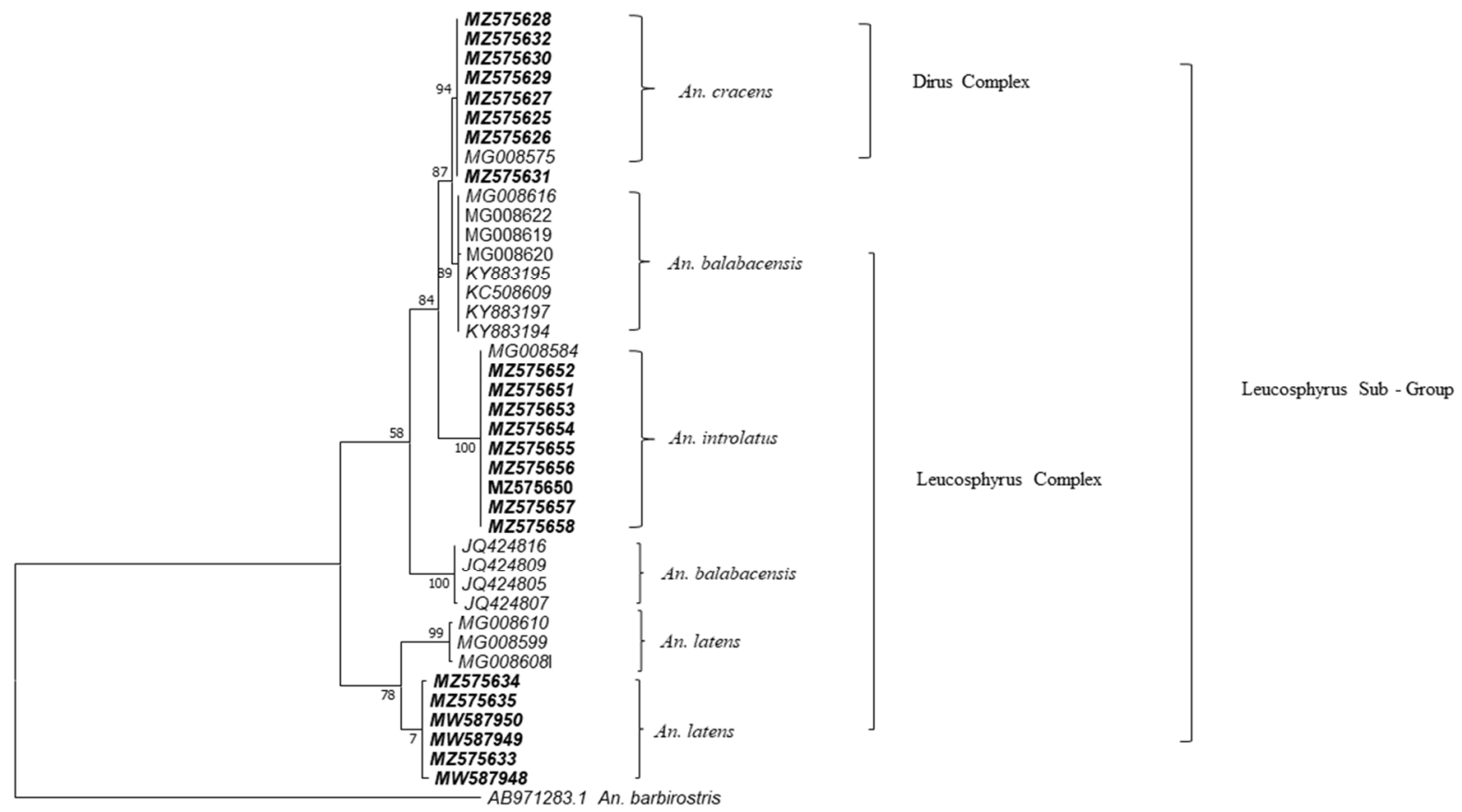

Figure 2. Phylogenetic tree of Anopheles Leucosphyrus group specimens sampled from six localities in Malaysia conScheme 2. sequence. The sequences in bold were deposited by this group, while unbold sequences are from Gene Bank.

The gel image (Figure 3) shows the specificity of the multiplex primers where only samples from the Leucosphyrus Group had been amplified while mosquitoes species from other groups were not successfully amplified by the designed primers.

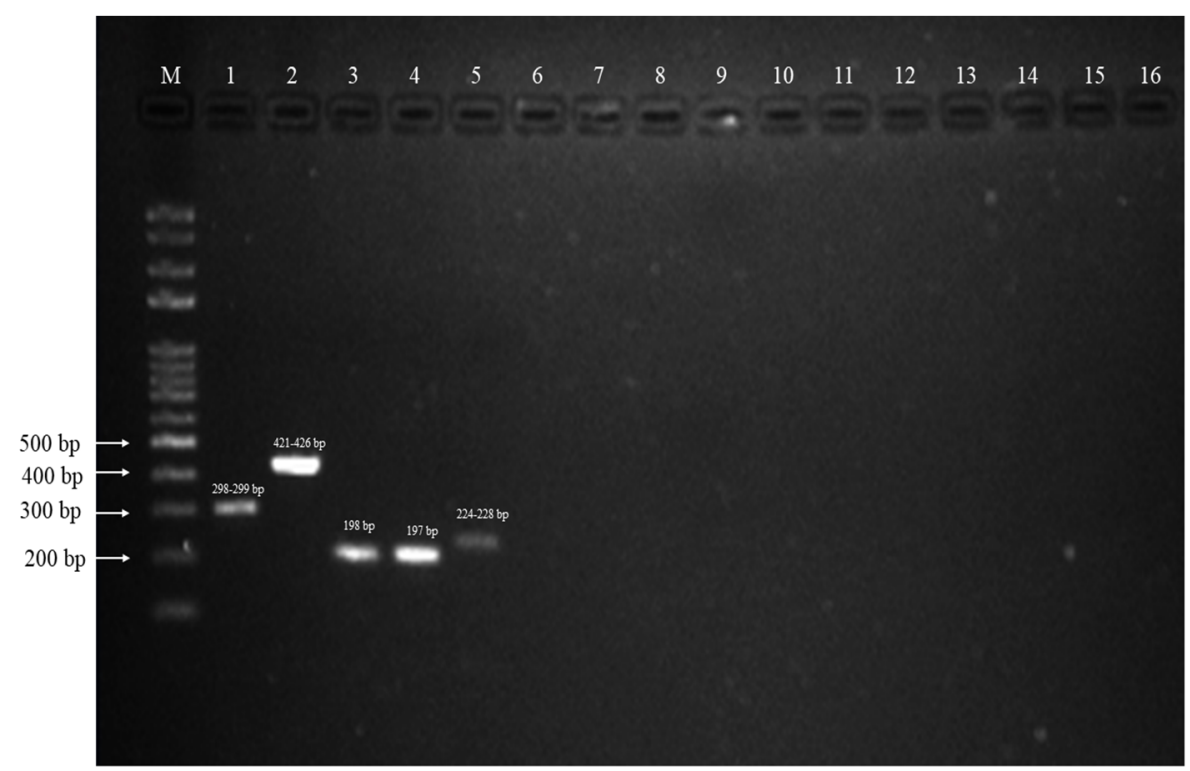

Figure 3. Products from the multiplex PCR run on a 1.5\% agarose gel. M, 100 bp plus ladder; lane 1, An. introlatus (298-299); lane 2, An. cracens (421-426); lane 3, An. latens clade I (198); lane 4, An. latens clade II (197); lane 5, An. balabacensis (224-228); lane 6, An. dirus; lane 7, An. minimus; lane 8, An. maculatus; lane 9, An. donaldi; lane 10, An. barbirostris; lane 11, An. sinensis; lane 12, An. aconitus; lane 13, Ar. subalbatus; lane 14, Ae. aegypti; lane 15, Ae. albopictus; and lane 16, negative control. 
Anopheles introlatus had $100 \%$ positive amplification. However, some of the samples tested were from DNA that was extracted some years ago, especially An. balabacensis and An. latens were not positive, perhaps due to the degradation of DNA. On the other hand, DNA extraction of old samples of whole mosquitoes preserved at $-20^{\circ} \mathrm{C}$ yielded positive bands by multiplex PCR (Table 2).

Table 2. Results from multiplex PCR on sequenced samples of Leucosphyrus Group of mosquitoes.

\begin{tabular}{ccccc}
\hline Species & No. of Specimen & No. of Sequenced Samples & \multicolumn{2}{c}{$\begin{array}{c}\text { Positive in Multiplex } \\
\text { PCR Assay }\end{array}$} \\
\hline An. balabacensis & 21 & 21 & 18 & 23 \\
An. cracens & 25 & 25 & 30 & 23.71 \\
An. introlatus & 30 & 30 & 100 \\
An. latens & 23 & 23 & 91.30 \\
\hline
\end{tabular}

\section{Discussion}

The geographical range of Leucosphyrus Group includes southwestern India eastwards to southern China, Taiwan, Southeast Asia's mainland, Indonesia, and the Philippines. [54,58]. Morphological criteria for the Leucosphyrus Group are sometimes difficult to be applied due to overlapping morphological characteristics. In order to study vectors in the light of control activities, correct identification of species and subsequent monitoring of Anopheles spp. is required to understand their spatial distributions, larval habitats, and population dynamics. Although the major important characteristics for species identification are scales on wings (wing patterns) and scales on legs, it is difficult to apply if the characters are destroyed during collections or storage [18,54]. For example, when a portion of the hindtarsome 4 is missing with pale scales at the base, females of An. introlatus can be incorrectly identified as Anopheles nemophilous of the Dirus complex [18]. Furthermore, the morphology of An. balabacensis is highly polymorphic, and thus characters used to differentiate the species between Leucosphyrus and Dirus complex, which are the presence of basal pale scales on hindtarsomere 4 and the existence of accessory sector pale (ASP) spots on vein C, subcosta, and $\mathrm{R}$ are important [59].

Currently, molecular markers are being used to solve identification problems. For accurate species identification, molecular markers, particularly the rRNA ITS2 gene, are used to distinguish between sibling species in several Asian Anopheles complexes such as An. minimus group [46], An. hycarnus group [47], An. dirus [45], An. maculatus [48], and An. fluviatilis [49]. The developed multiplex PCR in this study is useful in differentiating all four major Leucosphyrus species found in Malaysia. The multiplex PCR was validated on 122 specimens collected throughout Malaysia with a wide sampling range (Figure 1). The forward primer in our technique is universal, but the reverse primers are species specific. Molecular tools are more convenient in field studies since specimens could be dried and usually need only a small amount of tissue, such as mosquito legs.

Furthermore, the two An. latens clades that cannot be differentiated by the multiplex PCR assay based on PCR product size, are most likely linked to two different geographical regions, i.e., Peninsular Malaysia and Malaysian Borneo. Genetic variation was observed between An. latens from Peninsular and Borneo Malaysia. This may be due to the geographical separation between Peninsular Malaysia and Malaysian Borneo. Landscape factors influence the natural environment of species, resulting in genetic differences among the same species [60]. ITS2 is a well-acknowledged molecular marker for mosquito taxonomy as well as would be more reliable as a phylogenetic marker among closely related species $[61,62]$. However, to determine whether this species constitutes a cryptic species, a detailed morphological analysis is required for the An. latens from the two clades. Genetic diversity can be seen in the species complex. Anopheles balabacensis, Baisas is a complex species that has been recorded in a few countries. The two clades of An. balabacensis could be due to the cryptic diversity of that species [63]. However, the An. balabacensis primer 
was designed on the conserved region of sequences of both clades, which are predominant in Malaysia, as well as reliable sequences deposited in Gene Bank. A reverse primer for An. nemophilous species from the Malaysian Leucosphyrus Group has been developed and is awaiting validation pending the availability of field samples.

Accurate Anopheles species identification is essential in malaria vector surveillance because it influences the control intervention as well as pesticide product selection. Precise species identification allows for evaluations of vector competence, insecticide susceptibility, and important behavioural characteristics such as feeding and resting behaviours by species, leading to the development of insecticide-based control strategies that can be supplemented by additional malaria elimination techniques [57].

Proper species identification, involving both morphological and molecular techniques, is vital for species confirmation and vector ecology and for instituting effective control measures [64]. A few studies have demonstrated the importance of correct species identification in vector surveillance programmes. Anopheles minimus, a main malaria vector in India, was morphologically mistaken as An. fluviatilis, but each species was accurately identified using PCR of the ITS2 region [65]. If species are identified wrongly, it would be a serious problem, especially if it is a vector. Misidentification of Anopheles species could result in the wrong application of vector control measures $[29,66]$. Anopheles vaneedeni was also identified as a new malaria vector in South Africa during a malaria monitoring programme that used the ITS2 region for specific identification [67]. The technique suggested here allows for quick and reliable identification by requiring only PCR and electrophoresis of individual specimens. Identification of species for distribution purposes would aid in understanding the malaria distribution pattern as well as the development of vector and malaria preventative measures.

To reduce misidentification of the Malaysian Leucosphyrus Group of mosquitoes, a few steps must be taken. The first step is to correctly identify the samples morphologically. To avoid any misunderstanding regarding vector status, an ITS2 and cytochrome c oxidase subunit I (COI) sequence confirmation of the mosquito sample is required. Given the wide geographical distribution of the Leucosphyrus Group of mosquitoes and the involvement of plasmodia transmission, it is important to better know the exact diversity of species that comprise the complex as well as which ones are vectors of public health importance so that control efforts can be better targeted to maximise transmission suppression and increase the chances of malaria elimination [68]. As a result, an accurate identification approach based on molecular techniques is required to distinguish between species, allowing for further research into their bionomics, distribution, and role in disease transmission. The species of the mosquitoes cannot be determined solely through gel electrophoresis and estimation of the sizes of the PCR products unless the primers are species specific.

This current assay will be useful for molecular identification for the scenario where sequencing was not performed for the study. To our knowledge, this is the first multiplex PCR designed to identify the four simian malaria vectors of the Leucosphyrus Group of Anopheles mosquitoes in Malaysia. Previous studies have used the universal ITS2 A and ITS2 B primers to identify the species based on band size without sequencing [69]. This approach may not be accurate because the band size can be the same across species, especially when using universal primers [70]. It is essential to perform molecular identification to determine the species of the mosquitoes because misidentification can be detrimental. Many malaria control laboratories are already equipped to perform PCR tests; therefore, no new equipment will be required to identify, in this case, the Leucosphyrus Group species. The multiplex PCR test is fast, inexpensive, specific, and easy to use. Only a small amount of material (1-2 legs) is required for identification, leaving the remainder of the body parts available for further analysis, such as sporozoite detection, blood meal analysis, population genetics, or pesticide resistance status.

With P. knowlesi being the predominant species and with P. cynomolgi and P. inui affecting humans in Malaysia [5], it is vital to study the distribution and to correctly identify the vectors responsible for transmission. Accurate identification of vectors and 
their distribution for simian malaria parasites is essential to eventually help to implement malaria elimination strategy accordingly. Thus, this multiplex PCR technique will aid in the development of current knowledge on the species distribution of Leucosphyrus Group mosquitoes in large surveys of anopheline populations and large collections in Malaysia. Furthermore, since this technique does not rely on skilled interpretation, there is no subjective bias in the identification.

\section{Conclusions}

This study provides a quick, fast, specific, and effective multiplex PCR test for detecting the four Leucosphyrus Group species (An. balabacensis, An. cracens, An. introlatus, and $A n$. latens) known to be simian malaria vectors. This is a trustworthy identification technique that will enable a wide variety of investigations on the Leucosphyrus Group of species. The multiplex PCR can aid in identification if sequencing technology is not available. Correct species identification is critical in all downstream works concerning the species in question, especially for malaria vector control programmes. Further research work can be performed on more Anopheles species whose identities are reliably confirmed or developing complete primer sets for Anopheles Leucosphyrus Group of mosquitoes in Malaysia and the region.

Supplementary Materials: The following supporting information can be downloaded at: https: / / www.mdpi.com/article/10.3390/insects13020195/s1, Table S1: Details of Anopeheles Leucosphyrus Group of mosquitoes used in this study.

Author Contributions: Conceptualisation, I.V.; methodology, S.P. and J.W.K.L.; software, J.W.K.L.; validation, I.V., J.W.K.L. and V.L.L.; formal analysis, S.P.; investigation, S.P. and N.K.J.; resources, S.P. and N.K.J.; data curation, S.P.; writing — original draft preparation, S.P.; writing-review and editing, S.P., I.V., J.W.K.L., R.N. and V.L.L.; visualisation, I.V., J.W.K.L. and S.P.; supervision, I.V., J.W.K.L. and V.L.L.; R.N. project administration, S.P.; funding acquisition, I.V. All authors have read and agreed to the published version of the manuscript.

Funding: This research was funded by the Ministry of Higher Education of Malaysia Long-Term Research Grant Scheme (LRGS), grant no. LRGS 1/2018/UM/01/1/3.

Institutional Review Board Statement: The study was approved by Medical Research and Ethics Committee, Ministry of Health, Malaysia (NMRR-19-962-47606).

Informed Consent Statement: Informed consent was obtained from all subjects involved in the study.

Data Availability Statement: All data are available within the manuscript.

Acknowledgments: The authors extend their appreciation to the Ministry of Higher Education of Malaysia for Long-Term Research Grant Scheme (LRGS), funding this work through Supporting Project number (LRGS 1/2018/UM/01/1/3).

Conflicts of Interest: The authors declare no conflict of interest.

\section{References}

1. World Health Organization. World Malaria Report 2020: 20 Years of Global Progress and Challenges. Available online: https:/ / cdn.who.int/media/docs/default-source/malaria/world-malaria-reports/9789240015791-double-page-view.pdf? sfvrsn=2c24349d10 (accessed on 6 August 2021).

2. World Health Organization. WHO Certifies Sri Lanka Malaria-Free. Available online: https://www.who.int/southeastasia/ news / detail/05-09-2016-who-certifies-sri-lanka-malaria-free (accessed on 6 August 2021).

3. World Health Organization. From 30 Million Cases to Zero: China Is Certified Malaria-Free by WHO. Available online: https://www.who.int/news/item/30-06-2021-from-30-million-cases-to-zero-china-is-certified-malaria-free-by-who (accessed on 6 August 2021).

4. World Health Organization. Update on the E-2020 Initiative of 21 Malaria-Eliminating Countries: Report and Country Briefs. Available online: https:/ /apps.who.int/iris/bitstream/handle/10665/273633/WHO-CDS-GMP-2018.13-eng.pdf (accessed on 6 August 2021).

5. Jeyaprakasam, N.K.; Liew, J.W.K.; Low, V.L.; Wan-Sulaiman, W.-Y.; Vythilingam, I. Plasmodium knowlesi infecting humans in Southeast Asia: What's next? PLoS Negl. Trop. Dis. 2020, 14, e0008900. [CrossRef] [PubMed] 
6. Ta, T.H.; Hisam, S.; Lanza, M.; Jiram, A.I.; Ismail, N.; Rubio, J.M. First case of a naturally acquired human infection with Plasmodium cynomolgi. Malar. J. 2014, 13, 68. [CrossRef] [PubMed]

7. Grignard, L.; Shah, S.; Chua, T.H.; William, T.; Drakeley, C.J.; Fornace, K.M. Natural human infections with Plasmodium cynomolgi and other malaria species in an elimination setting in Sabah, Malaysia. J. Infect. Dis. 2019, 220, 1946-1949. [CrossRef] [PubMed]

8. Singh, B.; Kadir, K.A.; Hu, T.H.; Raja, T.N.; Mohamad, D.S.; Lin, L.W.; Hii, K.C. Naturally acquired human infections with the simian malaria parasite, Plasmodium cynomolgi, in Sarawak, Malaysian Borneo. Int. J. Infect. Dis. 2018, 73, 68. [CrossRef]

9. Imwong, M.; Madmanee, W.; Suwannasin, K.; Kunasol, C.; Peto, T.; Tripura, R.; Von Seidlein, L.; Nguon, C.; Davoeung, C.; Day, N.P.J.; et al. Asymptomatic natural human infections with the simian malaria parasites Plasmodium cynomolgi and Plasmodium knowlesi. J. Infect. Dis. 2019, 219, 695-702. [CrossRef]

10. Hartmeyer, G.N.; Stensvold, C.R.; Fabricius, T.; Marmolin, E.S.; Hoegh, S.V.; Nielsen, H.V.; Kemp, M.; Vestergaard, L.S. Plasmodium cynomolgi as cause of malaria in tourist to Southeast Asia. Emerg. Infect. Dis. 2019, 25, 1936-1939. [CrossRef]

11. Yap, N.J.; Hossain, H.; Nada-Raja, T.; Ngui, R.; Muslim, A.; Hoh, B.-P.; Khaw, L.T.; Kadir, K.A.; Divis, P.C.S.; Vythilingam, I.; et al Natural human infections with Plasmodium cynomolgi, P. inui, and 4 other simian malaria parasites, Malaysia. Emerg. Infect. Dis. 2021, 27, 2187-2191. [CrossRef]

12. Liew, J.W.; Bukhari, F.D.M.; Jeyaprakasam, N.K.; Phang, W.K.; Vythilingam, I.; Lau, Y.L. Natural Plasmodium inui infections in humans and Anopheles cracens Mosquito, Malaysia. Emerg. Infect. Dis. 2021, 27, 2700-2703. [CrossRef]

13. Ministry of Health. Press Statement Zoonotic Malaria and the Prevention Program in Malaysia 2018. Available online: https: //www.moh.gov.my/index.php/database_stores/attach_download/337/1087 (accessed on 7 August 2021).

14. Warren, M.; Wharton, R.H. The vectors of simian malaria: Identity, biology, and geographical distribution. J. Parasitol. 1963, 49, 892-904. [CrossRef]

15. Peyton, E.L. A new classification for the Leucosphyrus Group of Anopheles (Cellia). Mosq. Syst. 1989, 21, 197-205.

16. Sallum, M.; Peyton, E.L.; Wilkerson, R. Six new species of the Anopheles leucosphyrus Group, reinterpretation of An. elegans and vector implications. Med. Vet. Entomol. 2005, 19, 158-199. [CrossRef] [PubMed]

17. Manguin, S.; Garros, C.; Dusfour, I.; Harbach, R.; Coosemans, M. Bionomics, taxonomy, and distribution of the major malaria vector taxa of Anopheles subgenus Cellia in Southeast Asia: An updated review. Infect. Genet. Evol. 2008, 8, 489-503. [CrossRef]

18. Sallum, M.A.M.; Peyton, E.L.; Harrison, B.A.; Wilkerson, R.C. Revision of the Leucosphyrus Group of Anopheles (Cellia) (Diptera, Culicidae). Rev. Bras. Entomol. 2005, 49 (Suppl. 1), 1-152. [CrossRef]

19. Vythilingam, I.; Lim, Y.A.L.; Venugopalan, B.; Ngui, R.; Leong, C.S.; Wong, M.L.; Khaw, L.; Goh, X.; Yap, N.; Sulaiman, W.Y.W.; et al Plasmodium knowlesi malaria an emerging public health problem in Hulu Selangor, Selangor, Malaysia (2009-2013): Epidemiologic and entomologic analysis. Parasites Vectors 2014, 7, 436. [CrossRef] [PubMed]

20. Vythilingam, I.; Tan, C.H.; Asmad, M.; Chan, S.T.; Lee, K.S.; Singh, B. Natural transmission of Plasmodium knowlesi to humans by Anopheles latens in Sarawak, Malaysia. Trans. R. Soc. Trop. Med. Hyg. 2006, 100, 1087-1088. [CrossRef]

21. Wong, M.L.; Chua, T.H.; Leong, C.S.; Khaw, L.T.; Fornace, K.; Wan-Sulaiman, W.-Y.; William, T.; Drakeley, C.; Ferguson, H.M.; Vythilingam, I. Seasonal and spatial dynamics of the primary vector of Plasmodium knowlesi within a major transmission focus in Sabah, Malaysia. PLoS Negl. Trop. Dis. 2015, 9, e0004135. [CrossRef]

22. Vythilingam, I.; NoorAzian, Y.M.; Huat, T.C.; Jiram, A.I.; Yusri, Y.M.; Azahari, A.H.; NorParina, I.; NoorRain, A.; LokmanHakim, S. Plasmodium knowlesi in humans, macaques and mosquitoes in peninsular Malaysia. Parasit Vectors 2008, 1, 26. [CrossRef]

23. Wharton, R.H.; Eyles, D.E. Anopheles hackeri, a vector of Plasmodium knowlesi in Malaya. Science 1961, 134, 279-280. [CrossRef]

24. Van Bortel, W.; Trung, H.D.; Manh, N.D.; Roelants, P.; Verle, P.; Coosemans, M. Identification of two species within the Anopheles minimus complex in northern Vietnam and their behavioural divergences. Trop. Med. Int. Health 1999, 4, 257-265. [CrossRef]

25. Green, C.A.; Gass, R.F.; Munstermann, L.E.; Baimai, V. Population-genetic evidence for two species in Anopheles minimus in Thailand. Med. Vet. Entomol. 1990, 4, 25-34. [CrossRef]

26. Van Bortel, W.; Trung, H.D.; Roelants, P.; Harbach, R.E.; Backeljau, T.; Coosemans, M. Molecular identification of Anopheles minimus s.l. beyond distinguishing the members of the species complex. Insect Mol. Biol. 2000, 9, 335-340. [CrossRef] [PubMed]

27. Tananchai, C.; Tisgratog, R.; Juntarajumnong, W.; Grieco, J.P.; Manguin, S.; Prabaripai, A.; Chareonviriyaphap, T. Species diversity and biting activity of Anopheles dirus and Anopheles baimaii (Diptera: Culicidae) in a malaria prone area of western Thailand. Parasites Vectors 2012, 5, 211. [CrossRef] [PubMed]

28. Phuc, H.K.; Ball, A.J.; Son, L.; Hanh, N.V.; Tu, N.D.; Lien, N.G.; Verardi, A.; Townson, H. Multiplex PCR assay for malaria vector Anopheles minimus and four related species in the Myzomyia Series from Southeast Asia. Med. Vet. Entomol. 2003, 17, 423-428. [CrossRef] [PubMed]

29. Choochote, W.; Saeung, A. Anopheles Mosquitoes-New Insights into Malaria Vectors; IntechOpen: London, UK, 2013 ; pp. 57-79.

30. De Ang, J.X.; Yaman, K.; Kadir, K.A.; Matusop, A.; Singh, B. New vectors that are early feeders for Plasmodium knowlesi and other simian malaria parasites in Sarawak, Malaysian Borneo. Sci. Rep. 2021, 11, 7739. [CrossRef] [PubMed]

31. Paredes-Esquivel, C.; Donnelly, M.J.; Harbach, R.E.; Townson, H. A molecular phylogeny of mosquitoes in the Anopheles barbirostris Subgroup reveals cryptic species: Implications for identification of disease vectors. Mol. Phylogenet. Evol. 2009, 50, 141-151. [CrossRef] [PubMed]

32. Sungvornyothin, S.; Garros, C.; Chareonviriyaphap, T.; Manguin, S. How reliable is the humeral pale spot for identification of cryptic species of the Minimus Complex? J. Am. Mosq. Control Assoc. 2006, 22, 185-191. [CrossRef] 
33. Dusfour, I.; Blondeau, J.; Harbach, R.E.; Vythilingham, I.; Baimai, V.; Trung, H.D.; Sochanta, T.; Bangs, M.J.; Manguin, S. Polymerase chain reaction identification of three members of the Anopheles sundaicus (Diptera: Culicidae) complex, malaria vectors in Southeast Asia. J. Med. Entomol. 2007, 44, 723-731. [CrossRef]

34. Baimai, V.; Kijchalao, U.; Sawadwongporn, P.; Green, C.A. Geographic distribution and biting behaviour of four species of the Anopheles dirus complex (Diptera: Culicidae) in Thailand. Southeast Asian J. Trop. Med. Public Health 1988, 19, $151-161$.

35. Baimai, V. Population cytogenetics of the malaria vector Anopheles Leucosphyrus Group. Southeast Asian J. Trop. Med. Public Health 1988, 19, 667-680.

36. Baimai, V.; Harbach, R.; Kijchalao, U. Cytogenetic evidence for a fifth species within the taxon Anopheles dims in Thailand. J. Am. Mosq. Control Assoc. 1988, 4, 333-338.

37. Baimai, V.; Poopittayasataporn, A.; Kijchalao, U. Cytological differences and chromosomal rearrangements in four members of the Anopheles dirus complex (Diptera: Culicidae). Genome 1988, 30, 372-379. [CrossRef] [PubMed]

38. Baimai, V.; Thu, M.M.; Paing, M.; Maheswary, N.P. Distribution and chromosomal polymorphism of the malaria vector Anopheles dirus species D. Southeast Asian J. Trop. Med. Public Health 1988, 19, 661-665. [PubMed]

39. Poopittayasataporn, A.; Baimai, V. Polytene chromosome relationships of five species of the Anopheles dirus complex in Thailand. Genome 1995, 38, 426-434. [CrossRef] [PubMed]

40. Sawadipanich, Y.; Baimai, V.; Harrison, B.A. Anopheles dirus species E: Chromosomal and crossing evidence for another member of the dirus complex. J. Am. Mosq. Control Assoc. 1990, 6, 477-481. [PubMed]

41. Green, C.A.; Munstermann, L.E.; Tan, S.; Panyim, S.; Baimai, V. Population genetic evidence for species A, B, C and D of the Anopheles dirus complex in Thailand and enzyme electromorphs for their identification. Med. Vet. Entomol. 1992, 6, 29-36. [CrossRef]

42. Panyim, S.; Yasothornsrikul, S.; Tungpradubkul, S.; Baimai, V.; Rosenberg, R.; Andre, R.G.; Green, C.A. Identification of isomorphic malaria vectors using a DNA probe. Am. J. Trop. Med. Hyg. 1988, 38, 47-49. [CrossRef]

43. Audtho, M.; Tassanakajon, A.; Boonsaeng, V.; Tpiankijagum, S.; Panyim, S. Simple nonradioactive DNA hybridization method for identification of sibling species of Anopheles dirus (Diptera: Culicidae) complex. J. Med. Entomol. 1995, 32, 107-111. [CrossRef]

44. Manguin, S.; Kengne, P.; Sonnier, L.; Harbach, R.E.; Baimai, V.; Trung, H.D.; Coosemans, M. SCAR markers and multiplex PCR-based identification of isomorphic species in the Anopheles dirus complex in Southeast Asia. Med. Vet. Entomol. 2002, 16, 46-54. [CrossRef]

45. Walton, C.; Handley, J.M.; Kuvangkadilok, C.; Collins, F.H.; Harbach, R.E.; Baimai, V.; Butlin, R. Identification of five species of the Anopheles dirus complex from Thailand, using allele-specific polymerase chain reaction. Med. Vet. Entomol. 1999, 13, 24-32. [CrossRef]

46. Pramasivan, S.; Ngui, R.; Jeyaprakasam, N.K.; Liew, J.W.K.; Low, V.L.; Hassan, N.M.; Sulaiman, W.Y.W.; Jaraee, R.; Rahman, R.A.; Jelip, J.; et al. Spatial distribution of Plasmodium knowlesi cases and their vectors in Johor, Malaysia: In the light of human malaria elimination. Malar. J. 2021, 20, 426. [CrossRef]

47. Yusof, R.; Lau, Y.L.; Mahmud, R.; Fong, M.Y.; Jelip, J.; Ngian, H.U.; Mustakim, S.; Hussin, H.M.; Marzuki, N.; Mohd Ali, M. High proportion of knowlesi malaria in recent malaria cases in Malaysia. Malar. J. 2014, 13, 168. [CrossRef] [PubMed]

48. Vythilingam, I.; Foo, L.C.; Chiang, G.L.; Chan, S.T.; Eng, K.L.; Mahadevan, S.; Mak, J.W.; Singh, K.I. The impact of permethrin impregnated bednets on the malaria vector Anopheles maculatus (Diptera: Culicidae) in aboriginal villages of Pos Betau Pahang, Malaysia. Southeast Asian J. Trop. Med. Public Health 1995, 26, 354-358. [PubMed]

49. Jeyaprakasam, N.K.; Pramasivan, S.; Liew, J.W.K.; Van Low, L.; Wan-Sulaiman, W.-Y.; Ngui, R.; Jelip, J.; Vythilingam, I. Evaluation of Mosquito Magnet and other collection tools for Anopheles mosquito vectors of simian malaria. Parasites Vectors 2021, 14, 184. [CrossRef] [PubMed]

50. Reid, J.A. Anopheline Mosquitoes of Malaya and Borneo; Government of Malaysia: Kuala Lumpur, Malaysia, 1968.

51. Garros, C.; Koekemoer, L.L.; Coetzee, M.; Coosemans, M.; Manguin, S. A single multiplex assay to identify major malaria vectors within the African Anopheles funestus and the Oriental An. minimus groups. Am. J. Trop. Med. Hyg. 2004, 70, 583-590. [CrossRef]

52. Hempolchom, C.; Otsuka, Y.; Baimai, V.; Thongsahuan, S.; Saeung, A.; Taai, K.; Srisuka, W.; Somboon, P.; Choochote, W. Development of a multiplex PCR assay for the identification of eight species members of the Thai Hyrcanus Group (Diptera: Culicidae). Appl. Entomol. Zool. 2013, 48, 469-476. [CrossRef]

53. Walton, C.; Somboon, P.; O'Loughlin, S.; Zhang, S.; Harbach, R.; Linton, Y.-M.; Chen, B.; Nolan, K.; Duong, S.; Fong, M.-Y.; et al Genetic diversity and molecular identification of mosquito species in the Anopheles maculatus group using the ITS2 region of rDNA. Infect. Genet. Evol. 2007, 7, 93-102. [CrossRef]

54. Manonmani, A.; Townson, H.; Adeniran, T.; Jambulingam, P.; Sahu, S.; Vijayakumar, T. rDNA-ITS2 polymerase chain reaction assay for the sibling species of Anopheles fluviatilis. Acta Trop. 2001, 78, 3-9. [CrossRef]

55. Taai, K.; Harbach, R.E. Systematics of the Anopheles barbirostris species complex (Diptera: Culicidae: Anophelinae) in Thailand. Zool. J. Linn. Soc. 2015, 174, 244-264. [CrossRef]

56. Dahan-Moss, Y.; Hendershot, A.; Dhoogra, M.; Julius, H.; Zawada, J.; Kaiser, M.; Lobo, N.F.; Brooke, B.D.; Koekemoer, L.L. Member species of the Anopheles gambiae complex can be misidentified as Anopheles leesoni. Malar. J. 2020, 19, 89. [CrossRef]

57. Bang, W.J.; Kim, H.C.; Ryu, J.; Lee, H.S.; Lee, S.Y.; Kim, M.S.; Chong, S.T.; Klein, T.A.; Choi, K.S. Multiplex PCR assay for the identification of eight Anopheles species belonging to the Hyrcanus, Barbirostris and Lindesayi groups. Malar. J. 2021, $20,287$. [CrossRef] 
58. Beebe, N.; Cooper, R. Systematics of malaria vectors with particular reference to the Anopheles punctulatus group. Int. J. Parasitol. 2000, 30, 1-17. [CrossRef]

59. Sallum, M.A.M.; Foster, P.G.; Li, C.; Sithiprasasna, R.; Wilkerson, R.C. Phylogeny of the Leucosphyrus Group of Anopheles (Cellia) (Diptera: Culicidae) Based on Mitochondrial Gene Sequences. Ann. Entomol. Soc. Am. 2007, 100, 27-35. [CrossRef]

60. Keller, D.; Holderegger, R.; van Strien, M.J.; Bolliger, J. How to make landscape genetics beneficial for conservation management. Conserv. Genet. 2015, 16, 503-512. [CrossRef]

61. Marrelli, M.T.; Sallum, M.A.M.; Marinotti, O. The second internal transcribed spacer of nuclear ribosomal DNA as a tool for Latin American anopheline taxonomy. Memórias Do Inst. Oswaldo Cruz 2006, 101, 817-832. [CrossRef] [PubMed]

62. Wesson, D.M.; Porter, C.H.; Collins, F.H. Sequence and secondary structure comparisons of ITS rDNA in mosquitoes (Diptera: Culicidae). Mol. Phylogenet. Evol. 1992, 1, 253-269. [CrossRef]

63. Widiarti, W.; Garjito, T.; Widyastuti, U. Diversitas Genetik Anopheles balabacensis, Baisas di Berbagai Daerah Indonesia Berdasarkan Sekuen Gen ITS 2 DNA Ribosom. Indones. Bull. Health Res. 2016, 44, 20141. [CrossRef]

64. Erlank, E.; Koekemoer, L.L.; Coetzee, M. The importance of morphological identification of African anopheline mosquitoes (Diptera: Culicidae) for malaria control programmes. Malar. J. 2018, 17, 43. [CrossRef] [PubMed]

65. Singh, O.; Nanda, N.; Dev, V.; Bali, P.; Sohail, M.; Mehrunnisa, A.; Adak, T.; Dash, A. Molecular evidence of misidentification of Anopheles minimus as Anopheles fluviatilis in Assam (India). Acta Trop. 2010, 113, 241-244. [CrossRef]

66. Hunt, R.; Mahon, R. Collections of Anopheles-Quadriannulatus (Diptera, Culicidae) From Human Habitations in Southern-Africa. J. Entomol. Soc. S. Afr. 1986, 49, 390-391.

67. Burke, A.; Dandalo, L.; Munhenga, G.; Dahan-Moss, Y.; Mbokazi, F.; Ngxongo, S.; Coetzee, M.; Koekemoer, L.; Brooke, B. A new malaria vector mosquito in South Africa. Sci. Rep. 2017, 7, 43779. [CrossRef]

68. Harbach, R.E. Anopheles Classification. Mosquito Taxonomic Inventory. Towards Malaria Elimination 2018. Available online: https:/ / www.intechopen.com/books/towards-malaria-elimination-a-leap-forward (accessed on 30 August 2021).

69. Ahmad, R.; Azahary, A.R.A.; Mohamed Nor, Z.; Wan Mohd Ali, W.N.; Ismail, Z.; Mohd Omar, H.; Mohd Majid, A.; Hamid, Z.; Ismail, S.; Lee, H.L. Comparative Human Landing Catch and CDC Light Trap in Mosquito Sampling in Knowlesi Malaria Endemic Areas in Peninsula Malaysia. Adv. Entomol. 2016, 4, 1-10. [CrossRef]

70. Sum, J.-S.; Lee, W.-C.; Amir, A.; Braima, K.A.; Jeffery, J.; Abdul-Aziz, N.M.; Fong, M.-Y.; Lau, Y.-L. Phylogenetic study of six species of Anopheles mosquitoes in Peninsular Malaysia based on inter-transcribed spacer region 2 (ITS2) of ribosomal DNA. Parasites Vectors 2014, 7, 309. [CrossRef] [PubMed] 